This is an Accepted Manuscript of an article published by SAGE in Journal of Sociology on 3 January 2013, available online: http://jos.sagepub.com/content/51/4/785.abstract

\title{
Social Control and Trust in the New Zealand Environmental
}

\section{Movement}

\section{Thomas O'Brien}

Centre for International Security and Resilience, Cranfield University at the Defence

Academy of the United Kingdom

t.obrien@cranfield.ac.uk

Escalating concern regarding environmental issues has resulted in an increase in the number and scope of environmental movements internationally. The diversity and proactive nature of these movements has put pressure on public (state) actors to address challenges and engage with movement actors. Engagement is not universally positive and can lead to attempts at disruption or subversion of challenging movements. This article examines the impact of perceived state subversion on trust within the New Zealand environmenteuttmovement through the alleged use of spies. The analysis finds that short-term emotional reactions within the movement that led to questioning of relationships were outweighed by longer-term pragmatic view about the need to maintain collective action.

Keywords: New Zealand, non-governmental organisations, trust, state, threat

\section{Introduction}

Emerging concern regarding environmental issues has seen an increase in the number and scope of environmental movements internationally. This paper adopts the definition of environmental movements provided by Rootes (2007: 610) that:

an environmental movement may be defined as a loose, noninstitutionalised network of informal interactions that may include, as well as individual and groups who have 
This is an Accepted Manuscript of an article published by SAGE in Journal of Sociology on 3 January 2013, available online: http://jos.sagepub.com/content/51/4/785.abstract

no organisational affiliation, organisations of varying degrees of formality, that are engaged in collective action motivated by shared identity of concern about environmental issues.

Groups and organisations within the environmental movement adopt a wide variety of methods in seeking to achieve their goals, ranging from lobbying through to direct action. The focus of claim-making can be on both public and private actors as movements seek to influence policies and practices in their area of interest. Faced with such claims, states adopt a range of strategies ranging from inclusion and active engagement through to exclusion and restriction of access (Dryzek et al 2003). The response is determined by the character of the issue area and the form of the claimmaking activities. When faced with claims that challenge the legitimacy or authority of the state, it may seek to use subversion to limit the effectiveness of such movements (Cunningham 2003).

The character of the environmental movement means that it relies heavily on the formation and maintenance of trust networks (Sønderskov 2008). Successful attempts by external actors to break into or influence these networks would seem to present a significant barrier to the environmental movement's achievement of effective outcomes. Examining attempts by the FBI to infiltrate and disrupt New Left protest movements in the 1960s, Cunningham (2003) argues that the perception of infiltration can lead to self-limiting behaviour that may be more damaging than the actual subversive activities. The perception that an organisation or movement is no longer able to operate without external interference will necessarily lead members to be more cautious about engaging external actors and expanding to include new members. The significance of this, as Tilly (2008) notes, is that perceived worthiness is a key feature of an effective movement. Without the ability to appeal openly to new members a 
This is an Accepted Manuscript of an article published by SAGE in Journal of Sociology on 3 January 2013, available online: http://jos.sagepub.com/content/51/4/785.abstract

movement may become increasingly irrelevant and ineffective, thereby undermining a key element of its purpose.

The environmental movement in New Zealand has occupied an important position within society since protests against plans to raise the level of Lake Manapouri in the 1960s (Mark et al 2001). However, the image of a clean, green, unspoilt country is being increasingly challenged by the neo-liberal drive of successive governments (Coyle and Fairweather 2005). As with environmental movements elsewhere, the movement in New Zealand has adopted a broad repertoire in pursuing its goals, from participation and collaboration with the state, through to demonstrations, marches and occupations (Dalton et al 2003; Downes 2000; O’Brien 2012a). Challenges presented by the movement have allegedly led some state enterprises to seek to undermine and challenge the coherence of the movement through the employment of spies to join movement groups and provide information on their activities. The aim of the article is to explore to what extent covert social control by the state has had an effect on trust within the movement. The article is divided into three sections. The first reviews the literature on the relationship between the state and civil society, with a focus on environmental NGOs. This section also examines factors that shape and influence the formation of trust within social movements. Following this, the article briefly covers the research method and the challenges in examining this issue. The third section examines the nature of the infiltration of the New Zealand environmental movement and to what extent it has impacted trust.

\section{Trust, Opportunities and State-Movement Relations}


This is an Accepted Manuscript of an article published by SAGE in Journal of Sociology on 3 January 2013, available online: http://jos.sagepub.com/content/51/4/785.abstract

The presence of an active and open civil society is important to the effective functioning of a social movement. Civil society provides the zone within which social movements operate, maintaining networks of trust and relations that sustain the emergence of social movement groups. Examining the nature of civil society, Linz and Stepan (1996: 7) note that it is:

an area of the polity where self-organizing groups, movements, and individuals, relatively autonomous from the state, attempt to articulate values, create associations and solidarities, and advance their interests. Civil society can include manifold social movements... and civic associations from all social strata

Although it is argued that civil society is relatively autonomous from the state, the latter does play an important role in shaping and directing the activities of civil society. In democratic regimes, the state provides the space where groups can gather and articulate how politics and society should be organised, as well as setting boundaries on what can be articulated (Chandhoke 2001). These boundaries are dependent on the context and the interests of the state, leading to the state attempting to maintain control.

Environmental movements emerged from this milieu in an attempt to raise awareness about significant environmental issues. As with other social movements, the environmental movement is a fluid entity, shifting in response to changes in the external context. Van der Heijden (1999) has noted that there has been an increasing trend towards professionalisation and institutionalisation, as movement groups and the movement itself seek to achieve increased credibility. This shift has been reflected more broadly with the emergence of a divide between formal established NGOs and more ephemeral grassroots organisations (Mercer 2002). The uncertain character of environmental issues entails a process of constant adjustment, feedback and 
This is an Accepted Manuscript of an article published by SAGE in Journal of Sociology on 3 January 2013, available online: http://jos.sagepub.com/content/51/4/785.abstract

negotiation between affected parties (Lidskog and Elander 2007). Flexibility to respond to these competing demands is reflected in the consensual, non-hierarchical and diverse character of environmental movements (see Downes 1996).

The contemporary New Zealand environmental movement emerged in the 1960s to oppose the expansion of hydroelectric power by raising the level of Lake Manapouri. Opposition to the plan was driven by the "potential environmental effects, and the secret and suspect government motives behind it." (Mills 2009: 684). Although the campaign was ultimately unsuccessful, it did lead to the emergence of an environmental movement, which coalesced in the 1970s around the logging of native forests. This opposition saw the formation of the Native Forests Action Council (NFAC) and local branches of Greenpeace and Friends of the Earth (Barnes and Hayter 2005; Downes 2000). The introduction of radical restructuring of government agencies and privatisation in the $1980 \mathrm{~s}$, followed by government attempts to depoliticise environmental issues from the 1990s dispersed the focus and weakened the cohesion of the movement (Buhrs 2003; Wheen 2002). This has resulted in a more professional approach to environmental opposition, as represented by the four main national groups (Greenpeace, Environmental Defense Society, World Wildlife Fund, and the Royal Forest and Bird Protection Society). Although certain issues (native forest logging and genetic engineering) have seen sustained opposition, much of the activities of the movement involve groups working with the state (see O'Brien 2012a).

The relationship between the state and social movement actors is complex. Attitudes of state actors are shaped by the issues concerned, the presence and strength of 
This is an Accepted Manuscript of an article published by SAGE in Journal of Sociology on 3 January 2013, available online: http://jos.sagepub.com/content/51/4/785.abstract

countermovement actors, and the institutional structures in place (Gale 1986). Where these aims are in conflict the state may seek to restrict or limit access to the formal administration in order to pursue government objectives. In such situations the state may adopt an instrumental approach to participation, providing enough access to ensure that levels of protest and opposition are limited, while continuing to rely on technical solutions that exclude concerns that do not fit the predetermined frame (Dryzek et al 2003; Todt 1999). The tension between the need to allow participation while potentially limiting its effect is significant in areas of environmental concern, as such issues tend to be more outcome-focused (Parkins and Mitchell 2005) and more reliant on expertise than other issue areas (Todt 1999). In addition to reacting to pressures from within social movement organisations, the state may seek to exert influence over their operation. State intervention of this sort takes a range of forms, depending on the character of the challenge and the nature of the claim being made.

When faced with pressure from social movements the state may also choose to adopt covert measures to disrupt or undermine the operation of movement organisations. As Rootes (2007: 610) argues, "a social movement is not a natural object but a social construct", requiring effort to sustain cooperation where competing goals emerge and making them susceptible to external interference and disruption. Marx (1974: 403) furthers this position, arguing that "the efforts of the larger society to control or accommodate to social movements (particularly protest groups) should be viewed as an integral part of the environment of these groups." This point is supported by Cunningham and Noakes (2008: 179), who argue that:

Forms of state repression...can be understood as having an impact on social movements through their effect on the cost-benefit calculus undergone by activists and potential activists or potential participants... [and] the immediate impact of state 
This is an Accepted Manuscript of an article published by SAGE in Journal of Sociology on 3 January 2013, available online: http://jos.sagepub.com/content/51/4/785.abstract

action on individuals' decision to participate generates an indirect and more global chilling effect as a potentially large pool of contributors quickly erodes to a smaller, more marginalized grouping of participants.

Where there is a perception that state agents are attempting to infiltrate social movement organisations the ability to form and maintain broader networks (that rely on thin trust) will be weakened. It has been noted that the "Discovery of an agent (and even perception of the myth of an agent) may lead to feelings of demoralization, helplessness, cynicism, and immobilising paranoia, and can serve to disintegrate a movement" (Marx 1974: 428). The maintenance of thin trust is essential to the operation of the social movement.

The informal and voluntary character of environmental movements also means that they rely heavily on trust to form and maintain networks. Environmental movements utilise two forms of trust: 'thin', linking and 'thick', binding organisations. Anheier and Kendall (2002: 350) note that "thin trust or social trust, [is] based on everyday contacts, professional and acquaintance networks, [and] involves a much greater number of ties that form less dense relations." By contrast, thick (or particularistic) trust is based on fewer stronger ties that derive from shared identity or experience. These connections are more robust and as such can impose a greater burden on the participants to conform. Uslaner (2002: 9) reinforces the importance of trust by arguing that "People willing to take the risk of dealing with a wide range of other people may reap the rewards of solving larger-scale collective action problems".

Environmental movements therefore rely on a combination of thin and thick trust. Thin trust enables diverse groups to work together to address particular issues of common interest, as was seen in New Zealand with the opposition to genetic 
This is an Accepted Manuscript of an article published by SAGE in Journal of Sociology on 3 January 2013, available online: http://jos.sagepub.com/content/51/4/785.abstract

engineering (O’Brien 2012a). At the same time thick trust also plays an important role in forming collective identities within groups and parts of the wider environmental movement. Examining environmental groups in London, Saunders (2007) found a clear distinction between three sub-types within the environmental movement: conservationists, reformists, and radicals. Although groups identified as such had working relationships, the ties tended to be much stronger between groups with similar aims and methods. Development of collective identities at group level was also found to work against the development of a broader identity at the movement level (Saunders 2008). The result is that where thick forms of trust (within groups) come to dominate thin trust (between groups) opportunities to form broad networks necessary to achieve environmental movement aims may be restricted.

It is therefore important to examine and understand the factors that serve to undermine or limit the development of thin trust. Thin trust is based on connections that impose a relatively small burden on the parties concerned, making the loss of the connection less important than a connection based on thick trust. However, while the loss of a connection may not weigh heavily on the individual, a cumulative loss of trust can have devastating effects. The relatively fragile nature of thin trust and the fact that it generally acts as a bridge between actors or groups means that it may be particularly vulnerable to external influences. Examining the importance of the external environment in encouraging factionalism and schism within social movement organisations, Balser (1997: 212) identifies four categories, two of which are directly relevant to the maintenance of trust networks: “(1) political opportunity structures, [and] (2) social control mechanisms." A consideration of these categories in the 
This is an Accepted Manuscript of an article published by SAGE in Journal of Sociology on 3 January 2013, available online: http://jos.sagepub.com/content/51/4/785.abstract

context of a broader social movement context is useful for generation of valuable insights into the maintenance of trust networks.

Political opportunity structures have been identified as important external factors in shaping the ability and willingness of social movement organisations to function (Tilly 2008). Balser (1997) notes that changes in the political opportunity structure can lead to the breakup of social movement organisations as members seek to pursue different aims, as new opportunities present themselves. In the context of trust networks this can have a positive impact, as the search for new opportunities entails the creation of new connections and attempts to extend or strengthen existing ties. Conversely, attempts by the state to extend social control mechanisms and a closing down of political opportunities will likely lead to a weakening of networks and an undermining of thin trust. In cases where covert social control is being exercised by the state (or countermovement), participants in the social movement may feel restricted and seek to limit their exposure to those outsiders. Anheier and Kendall (2002: 357) note that 'Being 'one of us' and 'speaking the right language' by using the right terms and labels in addressing members is a necessary condition in generating interpersonal trust and a readiness for collective action". However, this is not sufficient in itself for the maintenance of trust within the movement. Where there is a perception, correct or otherwise, that the movement has been infiltrated, the opportunities for extending this trust and building networks will be greatly reduced.

Although a relationship has been proposed between a lack of, or declining, opportunities, increasing threats, and social movement decline, it has also been argued that increasing threats can be a mobilising force. Goldstone and Tilly (2001: 183) 
This is an Accepted Manuscript of an article published by SAGE in Journal of Sociology on 3 January 2013, available online: http://jos.sagepub.com/content/51/4/785.abstract

argue that opportunity and threat need to be treated as independent factors in group decision making. Although a group may be aware of the costs of action it may "decide to risk protest, even if opportunities seem absent, if the costs of not acting seem too great." In the context of the environmental movement where the state uses infiltration to maintain control, groups and members will not necessarily abandon contentious action and may in fact increase their activities. Emotions can play an important role in this dynamic, as perceived attempts to disrupt the movement can reinforce boundaries between members and outsiders by increasing solidarity (Aminzade and McAdam 2001; Rodgers 2010). However, the nature of the change will lead to a heavier reliance on thick trust, potentially weakening the movement as a whole.

There is, by definition, an inherent challenge in assessing the extent of covert forms of social control exercised by the state over social movements. In the absence of detailed documentation of such activities (see Cunningham (2003) on FBI activities), it is difficult to determine how widespread such activities actually are. However, as noted above, the impact of perception of infiltration may be as significant as the reality. This provides an opportunity to examine whether the perception of social control (infiltration) undermines the formation and maintenance of broad (thin) trust networks necessary for cohesion within the environmental movement. This paper examines the effect of two high profile cases of alleged infiltration by state-owned enterprises into the New Zealand environmental movement, to assess the impact upon the movement.

\section{Methodology}


This is an Accepted Manuscript of an article published by SAGE in Journal of Sociology on 3 January 2013, available online: http://jos.sagepub.com/content/51/4/785.abstract

The research in this article draws on a series of interviews conducted with members and former members of environmental groups, non-governmental organisations, government officials, and academics. The interviews were part of a wider research project into environmental politics and policy-making in New Zealand. The topics covered in the interviews were public participation, competing interest groups, central-local government relations, media, public opinion regarding environmental issues, tactics adopted and challenges faced by environmental movement organisations, cohesion of the environmental movement. Requests for interview were sent to members of the environmental movement and government officials by a senior member of the movement on behalf of the researcher. This resulted in 17 interviews, 11 with environmental movement members and former members, five government officials and one environmental scientist. Interviews were conducted in person, over the phone, or on Skype between November 2010 and April 2011, lasting an average of 45 minutes. Interviews were recorded and transcribed, all interviewees checked the transcript to ensure accuracy and clarify any that were unclear. All relevant interviews were consulted in the preparation of this article.

In addition, the researcher contacted six members of the environmental organisations that were subject to covert activities as discussed in the cases below. Although those that responded expressed interest in the research subject once the researcher established his credentials, they were unwilling to participate in the project. The key reason given was a desire not to discuss their feelings regarding the alleged spying incidents, as this would risk strengthening the organisations that were involved in attempting to undermine their activities. The research therefore relies on interpretations of members of the wider environmental movement who had contact 
This is an Accepted Manuscript of an article published by SAGE in Journal of Sociology on 3 January 2013, available online: http://jos.sagepub.com/content/51/4/785.abstract

with members of the targeted organisations and who observed the events at close hand. The interconnected character of the environmental movement in New Zealand meant that the impact of the covert activities had resonance for those not directly connected (Interview former NGO member November 2010; see also Tucker 2012 on networks within anti-GM groups). It also draws on investigative newspaper reports of the events and online discussion of the lessons learned by members of the movement.

\section{Social Control and the New Zealand Environmental Movement}

The environmental movement in New Zealand has a diverse form, ranging from branches of large international environmental NGOs (Greenpeace, World Wildlife Fund) through active national organisations (Royal Forest and Bird Protection Society, Environmental Defence Society) to groups formed to publicise particular issues (GE Free New Zealand) (see Downes 2000; Barnes and Hayter 2005). These groups undertake a range of activities, with actions targeting all levels of the public sector as well as significant private sector organisations and industries (see O’Brien $2012 \mathrm{a} ; 2012 \mathrm{~b})$. The movement has therefore attracted the attention of the state and other actors. Within the last 15 years, two high-profile cases of alleged spying have occurred. In each case, state-owned enterprises (SOE) were alleged to have been using paid informants to gather information and undermine campaigns challenging their commercial activities. The attempts to disrupt the campaigns are significant as they provide an insight into the actions of the state when dealing with disruptive claim-making behaviour. ${ }^{1}$ The actions are also important as they have shaped perceptions within the environmental movement regarding the degree of opposition they faced. 
This is an Accepted Manuscript of an article published by SAGE in Journal of Sociology on 3 January 2013, available online: http://jos.sagepub.com/content/51/4/785.abstract

Reform of the New Zealand state from the mid-1980s to the mid-1990s involved a shift to what Boston (1998: 32) describes as a:

strong emphasis on performance management and strategic management; the institutional separation of the provision of policy advice from the delivery of services; the introduction of an output-based system of appropriations; and the widespread use of explicit "contracts" of various kinds...as a means of enhancing efficiency, accountability and control

Part of the reform process entailed the separation of "mainly commercial activities from the non-commercial ones and placing the former in company structures under the State-Owned Enterprise Act [1986]" (Boston 1998: 33). These new entities were required to balance profit-making with social and environmental responsibilities, with the non-interventionist stance of government resulting in a prioritisation of commercial interests (Boston 1998; Luke 2010). Pressure from these competing interests is also compounded by a highly visible position within the political sphere, with poor performance of SOEs being used as evidence of wider government failure (Luke 2010). The scale of the SOEs combined with their political visibility results in a need to ensure stable operation, which has allegedly led some to attempt infiltrate and disrupt oppositional environmental campaigns (see Hager and Mussen 2007; Hume 2006; Smeele 2000). A common feature of the cases that have been exposed is that they predominantly involve the use of independent third-party organisations. Examining the private sector security industry in New Zealand, Bradley and Sedgwick (2010) note that it has grown significantly in recent decades and that public sector organisations are important clients.

The important role played by large SOEs in the natural resource industries in New Zealand places constraints on the level of success that the environmental movement 
This is an Accepted Manuscript of an article published by SAGE in Journal of Sociology on 3 January 2013, available online: http://jos.sagepub.com/content/51/4/785.abstract

can achieve when acting in opposition. Examining the ownership of businesses engaged in natural resource production, McClintock and Taylor (2002) found that the state controlled over half of forestry production and the SOE Solid Energy operated most of the large coal mines. The commercial nature of the SOEs means that ability of the environmental movement to limit their actions is relatively limited. Drawing on Tilly's (2008: 92) classification of political opportunity structures, it is clear that these organisations tend to be relatively closed, elite dominated, and stable. Operating at arms-length from the state means that they are given a greater degree of freedom than formal government agencies due to their independent economic position. The result is that in challenging these organisations, the real focus of the movement's claims is the state, rather than the SOEs, in an attempt to capitalise on their political visibility. Further hampering these actions is the reliance of the New Zealand economy (nationally and regionally) on natural resource development.

In April 1997 a group of around 25 activists occupied trees in a native forest on the West Coast of the South Island in order to prevent logging by Timberlands West Coast Limited (TWCL) (The Press 1997a). Calling itself Native Forest Action (NFA), the group drew on techniques adopted elsewhere in obstructing the harvest of native timber (see Wright 1980; London 1998; Hayes 2006; Mallory 2006). The occupation was supplemented by protest gatherings targeted against firms purchasing the wood and directly against the state at Parliament and in other major centres (The Dominion 1997; The Press 1997b). Attempted talks between TWCL and NFA were frustrated by a lack of trust on both sides (The Press 1998), leading to a stalemate. Relations were strained further when it was discovered that a supporter of logging on the West Coast attended NFA meetings before leaving to form a countermovement organisation, 
This is an Accepted Manuscript of an article published by SAGE in Journal of Sociology on 3 January 2013, available online: http://jos.sagepub.com/content/51/4/785.abstract

Coast Action Network (Hager and Burton 1999). Although no direct connection between TWCL and the individual could be established, there was a perception that such a connection existed. This perception was reinforced when e-mails from a TWCL staff member claimed that the organisation was involved in a form of guerrilla warfare (Smeele 2000). The election of a Labour government in 1999 resulted in a change in the political environment, as logging was halted and TWCL was ultimately disbanded (see Memon and Wilson 2007; O’Brien 2012a).

Following in the footsteps of NFA, 75 members of a group calling itself Save Happy Valley (SHV) occupied the site of a proposed coal mine in January 2006. The action was initiated following an Environment Court decision granting permission for the Solid Energy to undertake mining activities (NZPA 2004). SHV responded by adopting a range of actions, including occupying the offices of Solid Energy, blocking coal transports, and conducting demonstrations at Parliament and in Christchurch (NZPA 2005a; NZPA 2005b; NZPA 2006). During the occupation, it was revealed that one of the members of SHV was being paid to infiltrate the group and feed information back to Solid Energy (Hager and Mussen 2007). In contrast with the NFA case, members of the media and SHV were able to establish that the informant was receiving payment for undertaking the work. Attempts to resolve the standoff between SHV and Solid Energy ultimately failed, with the result that the protest camp was dismantled in April 2009 and trespass notices were issued (The Press 2009). There was a lack of political will to halt mining on the West Coast, due to economic benefits for a marginal region (Conradson and Pawson 2009). 
This is an Accepted Manuscript of an article published by SAGE in Journal of Sociology on 3 January 2013, available online: http://jos.sagepub.com/content/51/4/785.abstract

These events had an important effect on the nature of the relationship between the environmental movement and the state. Discussing the feeling within the movement at the time of the SHV revelations a former NGO member stated that "the outrage was really quite visceral because it was such a betrayal of trust and a stripping bare of how vulnerable groups can be" (Interview December 2010). Reflecting on the feeling within the wider movement at the time, another former NGO member (Interview November 2010) commented that:

I think that for most groups it wasn't something that was necessarily going to affect the way they looked at incoming members...It was more a reflection of this is the environment that we are working in and this is the way that...[opponents] are looking at that.

The point being that although the intrusion represented a violation of the movement, it was not going to lead to significant change in the way involved groups acted. The difference in the subjective impact of the revelations is significant. The sense of betrayal conveyed in the first quote represents the more immediate reaction to the alleged infiltration. In contrast, the second response represents a longer-term acceptance of the context environmental movement actors operate in. This second view was reinforced by a senior member of the movement, who argued "When you seriously challenge vested interests that can have serious economic consequences, then you will find there are other consequences" (Interview NGO member April 2011). In this way, the actions of those being challenged are accepted as the cost if being involved in activism.

The exposure of an infiltrator led to attempts to learn from the experience. Although it was asserted that the risk of spying was not likely to impact recruitment strategies of the movement, it can be argued to have impacted the nature of trust. In an article on 
This is an Accepted Manuscript of an article published by SAGE in Journal of Sociology on 3 January 2013, available online: http://jos.sagepub.com/content/51/4/785.abstract

Indymedia (miss x 2008) discussing the exposure of a high-profile informant (involved in SHV) it was argued that, for many involved "everything suddenly clicked into place." The presence of an informant within the movement for 10 years led to questions regarding the nature of established relationships. The article goes on to note that although there were individual concerns regarding the behaviour of the individual these were not connected due to the informal and open nature of the movement, allowing him to operate unhindered. Central to this was the fact that "it is a big call to accuse someone of being a police informer" (miss x 2008). Interviewees argued that the experience would not significantly alter the nature of the movement, but it did lead to cautious treatment of new members in the immediate aftermath (Interview former NGO member November 2010). Expanding on this point another former member argued that detailed background vetting "is sort of counter to the spirit of collaborative, non-violent everything to say "right, show me your CV", (Interview December 2010). Although the movement has reflected on the signs and attempted to learn from them, these present new challenges as existing relationships are re-examined in the light of past experience.

The perception that the state is willing to use paid informants to infiltrate the environmental movement has impacted trust. This is reflected in the cautious reception the researcher received when seeking to conduct research on the issue of infiltration. Responses from former members of the affected organisations mentioned a desire not to discuss the issue publicly, as these discussions should be conducted within the movement. There was also a desire not to undermine future attempts at mobilization by discussing the effectiveness of state tactics. Discussions with members and former members revealed an awareness of the need to balance caution 
This is an Accepted Manuscript of an article published by SAGE in Journal of Sociology on 3 January 2013, available online: http://jos.sagepub.com/content/51/4/785.abstract

with the need to attract and encourage new members. The character of the movement means that relying solely on thick trust and collective identity will be self-defeating and may not deal with the issue of infiltration. It can be argued that while the presence of an informant can do harm in the short-term when acting as an agent provocateur (Marx 1974), it is the impact on trust (thin and thick) that is perhaps more significant to the continuing viability of the movement. In the cases examined the issue of infiltration was viewed as one that affected groups adopting more radical or disruptive methods, rather than those using conventional methods to try and influence government policy.

Trust within the environmental movement has proven to be relatively robust in the face of cases of infiltration. Rather than crumble, members of the movement have adjusted and adapted to the external context and adopted a pragmatic view. Challenges presented to SOEs by the movement have engendered responses that have undermined (thin) trust between these organisations and the environmental movement. However, there is recognition within the movement that the SOEs operate largely outside the control of the central state, being driven by commercial imperatives. This has allowed the environmental movement to maintain and develop relationships with the agencies of the state. Therefore, increasing differentiation of tasks undertaken by the state (Boston 1998) is recognised in how members of the environmental movement choose to engage, allowing thin trust between the movement and the state to co-exist alongside thick trust within the movement itself.

\section{Conclusion}


This is an Accepted Manuscript of an article published by SAGE in Journal of Sociology on 3 January 2013, available online: http://jos.sagepub.com/content/51/4/785.abstract

Trust is an important element in the functioning of environmental movements. Thick trust binds groups within the movement and facilitates the formation of collective identities. In contrast, thin trust allows these groups to work with other groups and individuals within the movement and externally. Attempts by the state to limit oppositional claims and actions through social control methods (such as infiltration) have the potential to disrupt thin trust, thereby undermining network relations and reinforcing boundaries between groups. In line with Goldstone and Tilly (2001), where members of the movement see the costs of not acting as too great, they are willing to bear the costs associated with action.

The perception of infiltration of the New Zealand environmental movement by state agents has had an important impact on relationships. Although the particular groups targeted operated on the periphery of the movement, in terms of organisation and methods, the character of the environmental movement meant that the effects were felt more widely. However, the revelations did not lead to a simple undermining of trust and the functioning of the movement. Members of the groups affected have continued to operate in different groups, while adopting a cautious approach to dealing with outsiders (as experienced by the researcher), thereby reinforcing boundaries. In the wider movement there was a feeling that the actions were aligned more closely with commercially driven SOEs rather than the agencies of the state that they deal with. As a result, the loss of thin trust has not been sustained, as members of the movement expressed an understanding of the need to maintain connections in order to achieve their ends. 
This is an Accepted Manuscript of an article published by SAGE in Journal of Sociology on 3 January 2013, available online: http://jos.sagepub.com/content/51/4/785.abstract

While the social and political context in New Zealand is distinct, there are broader lessons that can be drawn from an analysis of the case. Attempts by elements of the state to undermine or limit oppositional activity are not unified and the motivations of the organisations involved need to be examined. In this case commercial imperatives imposed on state agencies led to attempts to disrupt opposition. Rather than viewing the state as hostile, members of the movement noted that the commercial imperative of the SOEs drove their actions and that the same motivations did not necessarily apply in all parts of government. Trust has proven to be relatively robust, with members of the movement adopting a pragmatic, if cautious, approach recognising the importance of thin trust in continued collective action.

\footnotetext{
${ }^{1}$ Tarrow (2011: 99) argues that "Disruption is the source of much innovation in the repertoire and of the power in movement, but it is unstable and easily hardens into violence or becomes routinized into convention."
} 
This is an Accepted Manuscript of an article published by SAGE in Journal of Sociology on 3 January 2013, available online: http://jos.sagepub.com/content/51/4/785.abstract

\section{References:}

Aminzade, R. and McAdam, D. (2001) 'Emotions and Contentious Politics', pp. 1450 in R. Aminzade, J. Goldstone, D. McAdam, E. Perry, W. Sewell, Jr, S. Tarrow, and C. Tilly (ed.) Silence and Voice in the Study of Contentious Politics. Cambridge: Cambridge University Press.

Anheier, H. and Kendall, J. (2002) 'Interpersonal Trust and Voluntary Associations: Examining Three Approaches', British Journal of Sociology 53: 343-62.

Balser, D. (1997) 'The Impact of Environmental Factors on Factionalism and Schism in Social Movement Organizations', Social Forces 76: 199-228.

Barnes, T. and Hayter, R. (2005) 'No “Greek-Letter Writing”: Local Models of Resource Economies', Growth and Change 36: 453-70.

Boston, J. (1998) 'Public Sector Management, Electoral Reform and the Future of the Contract State in New Zealand', Australian Journal of Public Administration 57: 3243.

Bradley, T. and Sedgwick, C. (2010) 'Policing Beyond the Police: A "First Cut" Study of Private Security in New Zealand', Policing and Society 19: 468-92.

Buhrs, T. (2003) 'From Diffusion to Defusion: The Roots and Effects of Environmental Innovation in New Zealand', Environmental Politics 12: 83-101. 
This is an Accepted Manuscript of an article published by SAGE in Journal of Sociology on 3 January 2013, available online: http://jos.sagepub.com/content/51/4/785.abstract

Chandhoke, N. (2001) 'The "Civil" and the "Political" in Civil Society',

Democratization 8: 1-24.

Conradson, D. and Pawson, E. (2009) 'New Cultural Economies of Marginality:

Revisiting the West Coast, South Island, New Zealand', Journal of Rural Studies 25: 77-86.

Coyle, F. and Fairweather, J. (2005) 'Challenging a Place Myth: New Zealand's Clean Green Image Meets the Biotechnology Revolution', Area 37: 148-58.

Cunningham, D. (2003) 'State versus Social Movement: FBI Counterintelligence Against the New Left', pp. 45-77 in J. Goldstone (ed.) States, Parties and Social Movements. Cambridge: Cambridge University Press.

Cunningham, D. and Noakes, J. (2008) “"What if She's from the FBI?” The Effects of Covert forms of Social Control on Social Movements', pp. 175-97 in M. Deflem (ed.) Surveillance and Governance: Crime Control and Beyond. Bingley: Emerald Publishing/JAI Press.

Dalton, R., Recchia, R. and Rohrschneider, R. (2003) 'The Environmental Movement and the Modes of Political Action', Comparative Political Studies 36: 743-71.

Downes, D. 2000 'The New Zealand Environmental Movement and the Politics of Inclusion', Australian Journal of Political Science 35: 471-91. 
This is an Accepted Manuscript of an article published by SAGE in Journal of Sociology on 3 January 2013, available online: http://jos.sagepub.com/content/51/4/785.abstract

Downes, D. (1996) 'Neo-corporatism and Environmental Policy', Australian Journal of Political Science 31: 175-90.

Dryzek, J., Downes, D., Hunold, C., Schlosberg, D. and Hernes, H. (2003) Green States and Social Movements: Environmentalism in the United States, United Kingdom, Germany, and Norway. Oxford: Oxford University Press.

Gale, R. (1986) 'Social Movements and the State: The Environmental Movement, Countermovement, and Government Agencies', Sociological Perspectives 29: 20240.

Goldstone, J. and Tilly, C. (2001) 'Threat (and Opportunity): Popular Action and State Response in the Dynamics of Contentious Action', pp. 179-194 in R. Aminzade, J. Goldstone, D. McAdam, E. Perry, W. Sewell, Jr, S. Tarrow, and C. Tilly (ed.) Silence and Voice in the Study of Contentious Politics. Cambridge: Cambridge University Press.

Hager, N. and Burton, B. (1999) Secrets and Lies: The Anatonomy of an Antienvironmental PR Campaign. Nelson: Craig Potton Publishing.

Hayes, G. (2006) 'Vulnerability and Disobedience: New Repertoires in French Environmental Protests', Environmental Politics 15: 821-38.

Lidskog, R. and Elander, I. (2007) 'Representation, Participation and Deliberation? Democratic Responses to Environmental Challenge,' Space and Polity 11: 75-94. 
This is an Accepted Manuscript of an article published by SAGE in Journal of Sociology on 3 January 2013, available online: http://jos.sagepub.com/content/51/4/785.abstract

Linz, J. and Stepan, A. (1996) Problems of Democratic Transition and Consolidation:

Southern Europe, South America, and Post-Communist Europe. Baltimore, MD:

Johns Hopkins University Press.

London, J. (1998) 'Common Roots and Entangled Limbs: Earth First! and the Growth of Post-Wilderness Environmentalism', Antipode 30: 155-76.

Luke, B. (2010) 'Examining Accountability Dimensions in State-Owned Enterprises', Financial Accountability and Management 26: 134-62.

Mallory, C. (2006) 'Ecofeminism and Forest Defense in Cascadia: Gender, Theory and Radical Activism', Capitalism Nature Socialism 17: 32-49.

Mark, A., Turner, K. and West, C. (2001) 'Integrating Nature Conservation with Hydro-electric Development: Conflict Resolution with Lakes Manapouri and Te Anau, Fiordland National Park, New Zealand', Lake and Reservoir Management 17: $1-16$.

Marx, G. (1974) 'Thoughts on a Neglected Category of Social Movement Participant: The Agent Provocateur and the Informant', American Journal of Sociology 80: 40242.

McClintock, W. and Taylor, C. (2002) 'Business Ownership in Natural Resource Dependent Industries in New Zealand', paper prepared for $9^{\text {th }}$ International 
This is an Accepted Manuscript of an article published by SAGE in Journal of Sociology on 3 January 2013, available online: http://jos.sagepub.com/content/51/4/785.abstract

Symposium on Society and Resource Management, Indiana University, Bloomington, 2-5 June.

Memon, A. and Wilson, G. (2007) 'Contesting Governance of Indigenous Forests in

New Zealand: The Case of the West Coast Forest Accord', Journal of Environmental Planning and Management 50: 745-64.

Mercer, C. (2002) 'NGOs, Civil Society and Development: A Critical Review,' Progress in Development Studies 2: 5-22.

Mills, K. (2009) 'The Changing Relationship between Māori and Environmentalists in 1970s and 1980s New Zealand', History Compass 7: 678-700.

miss x (2008) 'NZ: The Beauty of Hindsight - Police Informant Caught after 10 Years', Indymedia http://de.indymedia.org/2008/12/237332.shtml [accessed:

$22 / 11 / 2011]$

O’Brien, T. (2012a) 'Environmental Protest in New Zealand (1997-2010)', British Journal of Sociology 63(4): 641-61.

O’Brien, T. (2012b) 'Fires and Flotillas: Opposition to Offshore Oil Exploration in New Zealand,' Social Movement Studies, ifirst. 
This is an Accepted Manuscript of an article published by SAGE in Journal of Sociology on 3 January 2013, available online: http://jos.sagepub.com/content/51/4/785.abstract

Parkins, J. and Mitchell, R. (2005) 'Public Participation as Public Debate: A

Deliberative Turn in Natural Resource Management', Society and Natural Resources 18: 529-40.

Rodgers, K. (2010) ““Anger is Why We're All Here”: Mobilizing and Managing Emotions in a Professional Activist Organization,' Social Movement Studies 9: 27391

Rootes, C. (2007) 'Environmental Movements', pp. 608-40 in D. Snow, S. Soule and H. Kriesi (ed.) The Blackwell Companion to Social Movements. Malden, MA:

Blackwell.

Saunders, C. (2008) 'Double-Edged Swords? Collective Identity and Solidarity in the Environmental Movement', British Journal of Sociology 59: 227-253.

Saunders, C. (2007) 'Using Social Network Analysis to Explore Social Movements: A Relational Approach,' Social Movement Studies 6: 227-43.

Sønderskov, K. (2008) 'Environmental Group Membership, Collective Action and Generalised Trust', Environmental Politics 17: 178-94.

Tarrow, S. (2011) Power in Movement: Social Movements and Contentious Politics ( $3^{\text {rd }}$ ed). Cambridge: Cambridge University Press.

Tilly, C. (2008) Contentious Performances. Cambridge: Cambridge University Press. 
This is an Accepted Manuscript of an article published by SAGE in Journal of Sociology on 3 January 2013, available online: http://jos.sagepub.com/content/51/4/785.abstract

Todt, O. (1999) 'Social Decision Making on Technology and the Environment in Spain', Technology in Society 21: 201-16.

Tucker, C. (2012) 'Using Social Network Analysis and Framing to Assess Collective Identity in the Genetic Engineering Resistance Movement of Aotearoa New Zealand', Social Movement Studies ifirst: 1-15.

Uslaner, E. (2002) The Moral Foundations of Trust. Cambridge: Cambridge University Press.

Van der Heijden, H. (1999) 'Environmental Movements, Ecological Modernisation and Political Opportunity Structures,' Environmental Politics 8: 199-221.

Wheen, N. (2002) ‘A History of New Zealand Environmental Law’, pp. 261-74 in E. Pawson and T. Brooking (ed) Environmental Histories of New Zealand. Melbourne: Oxford University Press.

Wright, L. (1980) 'Decision Making and the Logging Industry: An Example from New Zealand', Biological Conservation 18: 101-15.

\section{Newspapers:}


This is an Accepted Manuscript of an article published by SAGE in Journal of Sociology on 3 January 2013, available online: http://jos.sagepub.com/content/51/4/785.abstract

The Christchurch Press (1997a) 'Protest Action as Timberlands Meets', The

Christchurch Press 27 February.

The Christchurch Press (1997b) 'Kakariki Protests About W Coast Forest Accord', The Christchurch Press 9 June.

The Christchurch Press (1998) 'Leaked Beech Plans "Outdated”, The Christchurch Press 14 September.

The Christchurch Press (2009) 'Group Brings Protest to City', The Christchurch Press 24 April.

The Dominion (1997) 'Protestors Take to the Trees', The Dominion 19 July.

Hager, N. and Mussen, D. (2007) 'I Was Paid to Betray Protestors', Sunday StarTimes 27 May.

Hume, T. (2006) 'Yes, We Spy, Says Second Power Firm', Sunday Star-Times 7 May.

NZPA (2004) 'Protestors Occupy Proposed Mine Site', New Zealand Press Association 13 April.

NZPA (2005a) 'Cold and Rain May Drive Coal Protesters Away', New Zealand Press Association 7 March. 
This is an Accepted Manuscript of an article published by SAGE in Journal of Sociology on 3 January 2013, available online: http://jos.sagepub.com/content/51/4/785.abstract

NZPA (2005b) 'Protestors Lock Themselves to Rail Line - Stop Coal Trains', New Zealand Press Association 13 August.

NZPA (2006) 'Save Happy Valley Protesters Take to the Streets of Wellington', New Zealand Press Association 4 November.

Smeele, A. (2000) 'Emails Reveal Spies in Pro-And Anti-Logging Factions', New Zealand Press Association 28 January. 